\title{
Fiscal austerity and the health sector: the cost of adjustments
}

\author{
Austeridade fiscal e o setor saúde: o preço do ajuste
}

Romulo Paes-Sousa (https://orcid.org/0000-0002-3384-6657) ${ }^{1}$

Joyce Mendes de Andrade Schramm (https://orcid.org/0000-0003-1064-7484) ${ }^{2}$

Luiz Villarinho Pereira Mendes (https://orcid.org/0000-0002-9027-0287) ${ }^{2}$
${ }^{1}$ Centro de Pesquisas René Rachou, Fiocruz Minas. Av. Augusto de Lima 1715, Barro Preto. 30190-002 Belo Horizonte MG Brasil. romulo.paes@fiocruz.br ${ }^{2}$ Centro de Estudos Estratégicos, Fiocruz. Rio de Janeiro RJ Brasil.

\begin{abstract}
Fiscal austerity policies have been used as responses to economic crises and fiscal deficits in both developed and developing countries. While they vary in regard to their content, intensity and implementation, such models recommend reducing public expenses and social investments, retracting the public service and substituting the private sector in lieu of the State to provide certain services tied to social policies. The present article discusses the main effects of the recent economic crisis on public health based on an updated review with consideration for three dimensions: health risks, epidemiological profiles of different populations, and health policies. In Brazil, the combination of economic crisis and fiscal austerity policies is capable of producing a direr situation than those experienced in developed countries. The country is characterized by historically high levels of social inequality, an under-financed health sector, highly prevalent chronic degenerative diseases and persisting preventable infectious diseases. It is imperative to develop alternatives to mitigate the effects of the economic crisis taking into consideration not only the sustainability of public finance but also public well-being.
\end{abstract}

Key words Economic recession, economic policy, public policy, health systems, health care.
Resumo Políticas de austeridade fiscal têm sido utilizadas como respostas à crise econômica e deficit fiscal tanto em países desenvolvidos como em desenvolvimento. Embora variem quanto ao conteúdo, intensidade e cronograma de implementação, tais modelos preconizam a redução do gasto público, promovendo também a diminuição do investimento social, a retração da máquina pública e a substituição do Estado pelo setor privado na provisão de determinados serviços vinculados a políticas sociais. Este artigo debate os principais efeitos da crise econômica recente sobre a saúde da população, tendo sido baseado em uma revisão atualizada, considerando-se três dimensões: riscos à saúde, perfil epidemiológico das populações e políticas de saúde. A crise econômica no Brasil, combinada com a política de austeridade fiscal, pode produzir um contexto mais grave do que o vivenciado pelos países desenvolvidos. O país apresenta altos niveis históricos de desigualdade social, subfinanciamento do setor saúde, alta prevalência de doenças crônico-degenerativas e persistência de doenças infeciosas evitáveis. É imperativo que se construam alternativas para se mitigar os efeitos da crise econômica, levando-se em conta não apenas a sustentabilidade das finanças públicas, mas também o bem-estar da população.

Palavras-chave Recessão econômica, Política econômica, Política pública, Sistemas de saúde. 


\section{Introduction}

From the initial decades of the 20th century, the choice of strategy in how to face economic crises has pitted supporters of austerity against those in defense of economy stimulus. In its most classic format, opposing policies emerge either with an emphasis on reducing public expenses to reach fiscal balance or, on the other hand, on producing economic growth precisely through an increase in public spending. Such choices can have different impacts on the economy at different times and various consequences on jobs and the supply of goods and public services. Of course, it should be taken into consideration that fiscal balance is a central part of the economic agendas both of those who push for austerity and those who consider themselves in favor of stimulus policies.

The role of taxation in austerity or stimulus models is another story altogether. From a classic perspective, reduced public spending should be accompanied by an increased tax burden to reach fiscal balance quicker. However, increases in taxes have been used more sparingly within Latin America's liberal circles ${ }^{1}$, which has meant that efforts to achieve fiscal sustainability have, more often than not, been attempted through reduced public spending.

Stuckler \& Basu $^{2}$ observe that a scenario does not exist in which an austerity - or development-driven policy is imposed homogeneously as such choices vary according to a given government's ideological profile. Opting for austerity policies impacts significantly on the public's immediate well-being and the desired outcomes of a given model are not always attained. In other words, austerity has not necessarily provided the countries and regions that adopted such strategies with greater fiscal balance. Likewise, economic stimulus measures have not always led to increased social well-being. The prevailing political and economic circumstances in which any given measures are implemented influence the chosen model's chances of success.

As a response to unbalanced public accounts, the economic austerity programs practiced in several European countries have also been applied in Latin America. While they vary in regard to their content, intensity and implementation time line, such models recommend reducing public expenses and social investments, retracting the public service and substituting the private sector in lieu of the State to provide certain services tied to social policies. Obviously, each country's political dynamics will determine the extent to which each of such components is actually fulfilled.

As for Brazil, the country's Unified Health System (SUS for its initials in Portuguese) is based on the principle of universal access to comprehensive healthcare. Yet, implementing the SUS has, for several years, been difficult owing to a limited real capacity to adequately provide goods and healthcare services in a way that lives up to the principle of comprehensiveness and universality. While there is consensus regarding the deficient quality of a great deal of its services, a polarized debate has taken place between academics, technicians and practitioners in the public health sector and related fields with respect to the causes of the crisis. And the controversy is not limited to the dichotomy between insufficient resources and poor management. It includes debate on the extent to which Brazil's health sector reform was effectively carried out, the financial sustainability of a public system with the characteristics of the SUS and, of course, the healthcare-related goods and services that should be considered attributable to the public or private sectors ${ }^{3}$.

The private sector is also facing the crisis in its own way. In the 1990s, the private sector expanded rapidly, helped along by increased State intervention, and acquired more complex services. Internal market growth followed in subsequent decades owing to increasing income levels in Brazil's population ${ }^{4}$. However, this growth was achieved despite a model characterized by irrationally scaled hospital services, lacking professionalization of management, inadequate geographic distribution and an inefficient pay model with either State intervention or direct remuneration ${ }^{5}$. Both sectors ended up feeling the effects of the recent economic crisis, which worsened the existing problems. The public sector has been suffering longer given the stagnation of public funding, while the private sector was victim to increasing unemployment and the consequent retraction of corporate funding of health insurance, which was its main source of funding.

In 2016, Constitutional Amendment 95 was approved, ushering in a severe fiscal austerity package that entailed reduced investments in health and a subsequent reduction in the supply of goods and services, the effects of which would tend to penalize especially the poorest populations in addition to compromising the quality of public health services 6 .

The present article discusses the main effects of the recent economic crisis on public health based on an updated review of a similar study 
performed by the Fiocruz Centre for Strategic Studies $(\mathrm{CEE})^{7}$. Studies on the impacts of the economic crisis and austerity policies on public health were identified with consideration for three dimensions: health risks, epidemiological profiles of different populations, and health policies.

Generally speaking, studies on European countries and non-European countries of the OECD are most abundant in the scientific literature published between 2006 and 2019. There is a considerable number of studies on Greece, suggesting that the relevance of the economic crisis in this country and its potential spread to other countries of the European Union attracted the interest of researchers around the world. Our interest here is to assess possible scenarios that could develop in Brazil, naturally considering potential differences and particularities.

\section{Relationships between the crisis, structural adjustment (austerity) policies and public health}

The combined effects of the economic crisis and structural adjustment policies on health are, above all, those of greatest interest to countries in Latin America. After all, it is the region's strongest economies (Argentina, Brazil, Colombia and Mexico, until last year) which are implementing fiscal austerity policies ${ }^{8}$. When a country responds to the challenges of the global economic crisis with austerity policies entailing considerable shrinkage of social spending, the resulting contexts are considered as the crisis/austerity compound. In other words, the effects are considered as a whole in order to identify the intermediate determinants for variance of risks, health systems and services and public morbimortality ${ }^{9}$.

Figure 1 Depicts the framework used to assess how the effects of the crisis/austerity tend to affect the public and household spheres as well as their impacts on health in the public and individual spheres. The following sections explain the foundation of our model based on the evidence that was uncovered on this theme.

\section{Impacts on society and health services}

At the societal level, references were found regarding reduced spending on health by several actors. The health sector was affected in countries with: a national health system, such as the United Kingdom and Sweden; social insurance, such as Germany and Japan; and private insur- ance, such as the United States and Australia ${ }^{10}$. Indeed, several ways of funding and organizing health services have been subject to large cuts in health spending. In countries where there is considerable private sector participation in access to healthcare goods and services, such as in the United States, access was severely reduced for unemployed families. Also in the United States, the research discovered that donations to philanthropic health services also dropped. For a country with a hybrid healthcare model such as Brazil, where the public and private sectors are both prominent with philanthropic medicine also occupying a significant place, reduced access to goods and services can unfold in several ways. The public sector has been subject to greater pressure due to increased popular demand - by users who, up until the pre-crisis era, received service from the private or non-public sector - precisely in a period when investments in the public sector are being cut back.

In general, the literature review indicated impacts of reduced investments on all areas of the health sector: promotion, prevention, treatment, rehabilitation and palliative care. Investments in science and technology as well as management were also affected. Indeed, the studies indicate contractions in networks of facilities in several countries associated with reductions in human resources and inputs ${ }^{11}$. The effects of such scarcity, in turn, had repercussions on the quality of services provided, which also affected both administrative and managerial capacity.

The effects on public health expenditure are obviously the most visible component of austerity policies. Reeves et al. ${ }^{10}$ in an analysis of 27 European and non-European OECD countries in the period 1995 to 2011 observed the following:

The budget for the health sector was not preserved during crises. In some cases, they were subject to greater cutbacks, especially when loan agreements were negotiated with the International Monetary Fund (IMF);

Cuts to health sector spending were not an inevitable consequence of recessions, annual change in GDP per capita or cumulative losses in GDP;

The ideology of governing parties was not associated with cuts to the health sector;

Increased public debt among the countries in question, regardless of the amount, was associated with increased cuts to the health sector;

Receipt of loans from the IMF was strongly associated with the decision to reduce healthcare budgets; 


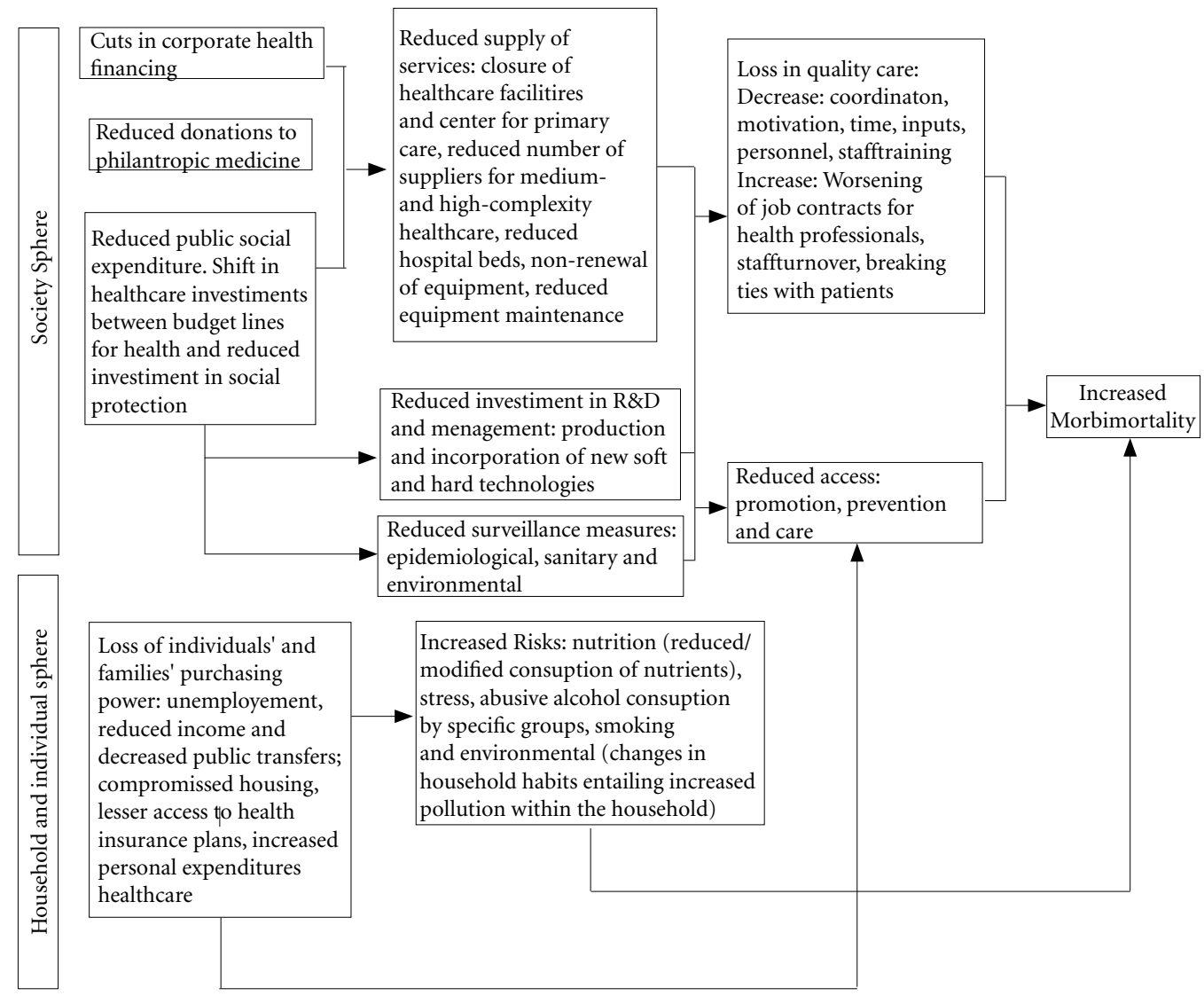

Figure 1. Impacts of the crisis/austerity compound on health.

Countries with social insurance systems were less susceptible to austerity policies, although they did appear to be more susceptible to declines in GDP per capita.

In a systematic review of the economic crisis on Greece from 2009 to 2013, Simou \& Koutsogeorgou ${ }^{11}$ observed the following effects on the country's health system:

Reduced public spending on health, both in service provision and management;

Reduced health sector workforce, reduced hours and losses in salaries and pensions;

Reduced supply of healthcare services including healthcare facilities and services provided by university hospitals;

Fluctuations in the pharmaceutical market, with increased consumption in the beginning of the period under observation - especially medication to treat psychological illnesses - followed by a decline in consumption, which led some drug manufacturing plants in the country to close;

Reduced funding for biomedical research.

Indeed, the quality of healthcare services in Greece was affected both by the constrained supply and willingness of professionals in the sector, whose performance was compromised by the prevailing stress in the private and professional spheres.

Grigorakis et al. ${ }^{12}$ highlight increased out-ofpocket costs for the Greek public as a result of the difficulties in accessing public health services. This phenomenon was aggravated by reduced household incomes, a consequence of unemployment, reduced salaries, reduced income transfers to social welfare, and shrinking reimbursement of medical expenses by health insurers.

Countries like Spain and Portugal, who also 
pursued austerity policies, have faced similar problems. Meanwhile in Iceland, where austerity policies were rejected by popular vote, investments in the health sector grew with diverse results 9

Vieira ${ }^{13,14}$, who performed a broad review of the effects of the economic crisis and fiscal austerity, indicates: 1) economic crises can aggravate social problems and increase social inequalities; 2) economic crises can worsen public health; 3 ) fiscal austerity measures that aim to reduce costs at the expense of social protection programs aggravate the effects of crisis on health, in particular, and more broadly on social conditions; and 4) preserving social protection programs is an important measure to protect public health and to ensure a quicker upturn for economic growth.

In the USA, it was observed that insured workers deferred seeking medical help and were less apt to take preventive measures as a way of protecting themselves against possible job loss as less healthy individuals ${ }^{15}$. Such behavior could entail deteriorations in health and a worse state of health when individuals do finally seek assistance from the health system.

The role of social protection policies is particularly highlighted in the scientific literature as a mitigating factor of the effects of unemployment and/or reduced income from work. Countries or provinces that maintained or reinforced their array of social welfare policies, including cash transfers to populations in poverty and extreme poverty, presented lower levels of mental illness and suicide ${ }^{9,12,16,17}$. In Italy, from 2000 to $2010, \mathrm{De}$ Vogli ${ }^{18}$ observed that social protection policies function as protective measures against increases in unemployment-related suicide.

\section{Impacts at the household and individual level}

At the household and individual level, the combination of unemployment and reduced cash transfers to poor population has substantially affected their habits and attitudes. Changes in diet and increased stress have been reported in many countries. Studies on alcohol abuse have produced contradictory results. At times it has reduced due to reduced purchasing power, while others it has increased as a response to increased tensions owing to worsening poverty within the household. The reduction or imminent reduction of purchasing power has affected how soon people will seek medical attention, either by deferring or not seeking it out altogether. They do so in order to reduce household expenses or to avoid the stigma of being in poor health and, thus, being vulnerable to inclusion in the group of workers who should be first to lose their jobs.

\section{Impacts on risk factors}

The worsening of risk factors owing to austerity policies is well documented in the literature. Such factors are, by definition, related to the emergence and worsening of illnesses and interact amongst themselves in a complex causal chain. Social, environmental, community and individual factors are among those in interaction in such chains.

For example, Gallus et al. ${ }^{19}$ observed differences in the prevalence of smokers in the USA in the period before the economic crisis (2005-2007) and thereafter (2009-2010). After correcting for several factors such as demographic growth and historical fluctuations in smoking patterns, the authors identified that the crisis was responsible for 2.4 million of new smokers in the unemployed population. In this way, they confirmed that unemployed individuals are more vulnerable to smoking in times of crisis.

Regarding alcohol consumption, one study used data from 2008 to 2009 from the National Alcohol Survey, a nation-wide study encompassing the USA, significant economic losses (unemployment or lost housing) were associated with the general increase of alcohol consumption and monthly drunkenness. Meanwhile, more moderate economic losses (late rent payments, reduced working hours) were not associated with alcohol consumption ${ }^{20}$. Other studies have observed increased alcohol consumption for specific groups ${ }^{2}$ and worse nutrition among the poorest households $^{21}$. Moreover, regarding Europe, a longitudinal study was carried out in 11 countries on persons aged 50 to 64 comparing their alcohol consumption habits in 2006 and 2012. The study concluded that loss of employment during the recession was an important risk factor for increased abusive alcohol consumption ${ }^{22}$.

\section{Crisis/Austerity and their impacts on mortality}

Studies on mortality related to economic recession have demonstrated that the historical trend of mortality reduction can, for diverse reasons, be subject to changes in speed, stagnation or even increases to the detriment of historical gains. The effects of economic crisis on mortality disproportionately affect different socio-eco- 
nomic groups, impacting particularly on the most vulnerable group ${ }^{23}$.

In an extensive review undertaken by Karanikolos et al. ${ }^{24}$ on the effects of the economic crisis in 2018 on general mortality, it was found that the shrinking tendency was maintained in European countries including Greece, which was the most affected country. The only exception to this observation was for infant deaths.

Phillips \& Nugent ${ }^{25}$ used data from 50 North American states to assess the effects of economic factors on increasing suicide rates. These authors found that, after decades of decline, suicide rates started to increase in 2005, especially among people aged 45 to 65 . Moreover, the authors identified a significant association between unemployment and suicide rates in several states. These associations were strongest in states with a greater female workforce, suggesting that the recession was at the root of a kind of anomie. The effects of unemployment on suicide rates did not appear to differ significantly with regard to the individual's sex.

Reeves et al. ${ }^{26}$ used multivariate statistical models to analyze changes in suicide rates in 20 European countries between 1981 and 2011. According to the findings, the recession was a critical determinant in changing suicide rates for males in different periods in Europe. Notably, spending on active labor market programs and higher levels of social capital appeared to mitigate the risk of suicide.

Regarding loss of housing, Fowler et al. ${ }^{27}$ used data from 16 states of the USA to show that this was a significant risk factor for suicide in times of economic crisis.

\section{Crisis/Austerity and their impacts on morbidity}

In a review of studies on Europe, Quaglio et al. ${ }^{28}$ observed the effects of economic crisis and austerity measures on Europeans. The authors found increases in the following illnesses, groups of illnesses or perceptions: anxiety, depression and alcoholism; communicable diseases; negative perceptions of health status. In a review focusing on Greece in the period 2009-2013, Simou \& Koutsogeorgou ${ }^{11}$ found studies indicating a correlation between the economic crisis and the following group of illnesses: mental illnesses, infectious diseases, hearing disorders and negative perceptions of health status. The studies converge in the finding that the largest impact was related to mental disorders.

\section{Mental Disorders}

The relationship between economic crisis and mental disorders is abundantly documented in the literature. Job loss, indebtedness, difficulties related to housing and other financial problems are stressful situations that worsen even more when coupled with government measures that reduce budgets and spending in healthcare. Most studies that investigate the impact of economic recessions on mental health focus on describing the changes in frequency of suicide attempts and the incidence of depression. The relationship between recession and mental health can be even more complex when its impacts are transferred to members of the family and spouses. Several studies have pointed out the greater relevance of recession, unemployment and financial hardship as social determinants of suicide attempts, followed by job loss and, in almost one in five attempts, ties to the loss of or reduced access to referral psychiatric services ${ }^{24,29-31}$.

The growing trend of depression and anxiety disorders after periods of economic turbulence has been observed in young adults - particularly a first episode of depression - while cases of recurring depression are observed in older individuals. Increased rates of depression in young adults appear to be a significant factor for increased prescriptions and consumption of medication. Barceló et al..$^{32}$ performed a retrospective cohort study (between 2005 and 2012) analyzing the consumption of psychotropic drugs by residents of the northeast region of Catalonia, Spain. The authors identified an increase in consumption of such medication in the period following the crisis (after 2009), especially among unemployed individuals and those who had previously used medication for mental disorders. The amount of medication ingested was identified as the factor having increased most, while that which grew least was the number of daily doses. Therefore, the authors concluded that the crisis contributed more significantly to increasing the severity of mental disorders - rather than their intensity - among individuals who already had such disorders previous to the crisis.

\section{Infectious Diseases}

Infectious diseases represent one of the greatest risk factors of economic growth in countries, regions and, indeed, the entire world. There is a certain consensus in the literature that economic crises can not only worsen the transmission of 
infectious diseases but can also limit the ability to control them. Such diseases, particularly in pandemic-like situations, can be responsible for mortality levels comparable to those associated with times of war, and can aggravate economic crises during periods of recession.

Europe has seen increases in HIV infections, the reappearance of malaria for the first time in 40 years, Nile fever and the reemergence of tuberculosis in Greece. Such change in the epidemiological landscape was related to the deteriorating economic situation in European countries ${ }^{24}$.

Kentikelenis et al..$^{33}$ conclude that migrants are especially vulnerable to infectious diseases during periods of crisis given their greater vulnerability to unemployment and poverty.

One systematic literature review sought to assess changes in the infectious disease burden following periods of $\mathrm{crisis}^{34}$. That study found evidence of worse infectious disease outcomes during recession, often resulting from higher rates of infectious contact between individuals in poorer living circumstances, worsened access to therapy or poorer retention in treatment. Groups at greater risk were the elderly, children, migrants, street dwellers and prisoner populations.

Reeves et al. ${ }^{35}$ analyzed 21 European countries in an attempt to assess the impacts of economic recession on the control of tuberculosis. The authors concluded that reductions in spending on public health services led to reduced tuberculosis case detection and increased long term risk of a resurgence in the disease. The European Centre for Disease Prevention and Control has estimated that untreated patients with tuberculosis infect close to 10-15 people annually. Therefore, reduced budgets for tuberculosis control programs entail diminished detection of cases and increases in treatment costs in the long term.

\section{Chronic Non-Communicable Diseases}

Karanikolos et al. ${ }^{24}$ identified an increase in the following clinical events, which are usually related to stress: hypertensive crises, acute myocardial infarction, diabetes and vertigo.

Andrikopoulos et al. ${ }^{36}$ studied health inequalities in cardiovascular disease outcomes following hospital discharge in 37 hospitals in Greece. For the authors, low income was a predictor of poor out-of-hospital outcome during periods of financial crisis.

Noelke \& Avendano ${ }^{37}$ performed a longitudinal study with national representativeness for the North American population aged older than 50.
Following 8,837 individuals between 1992 and 2010 , the authors concluded that during periods of recession, the risk of mortality from cardiovascular diseases reduced for individuals who kept their jobs and increased for those who lost their jobs.

Loerbroks et al. ${ }^{38}$ analyzed the association between job insecurity and asthma in Germany during the period of recession between 2009 and 2011 with a cohort of seven thousand individuals. The authors showed that a probability of losing one's job above 50\% (measured in 2009) was associated with a $60 \%$ risk of developing asthma (measured in 2011).

\section{Creating hypotheses on the effects of crisis/ austerity on health in Brazil}

In Brazil, the combination of economic crisis and fiscal austerity policies is capable of producing a direr situation than those experienced in developed countries. Recent signs suggest that several determinants of increased morbimortality are in the process of returning reduced investment in social protection, increasing poverty and the reemergence of communicable diseases via airborne vectors ${ }^{39}$. Indeed, the effects of the crisis and of austerity policies on the SUS could be devastating.

Between 2015 and 2017, the ECLAC (Economic Commission for Latin America and the Caribbean) $)^{40,41}$ estimated that poverty and extreme poverty had grown in Brazil by, respectively, $16.4 \%$ and $17.1 \%$. Accordingly, in 2017, 19.9\% of the country's population was living in poverty while $5.5 \%$ lived in extreme poverty. This is demonstrative of a rapid deterioration in the country's socio-economic indicators. The country's continuously modest economic growth associated with reduced public investment means that poverty and extreme poverty can be expected to intensify in the coming years.

Rasella et al. ${ }^{42}$, using econometric models, performed an estimate of changes in morbimortality in under-fives from 2017 to 2030. Their study indicates that possible cutbacks in funding to the Bolsa Familia (Family Subsidy) and Saúde da Família (Family Health) programs will lead to 20,000 more deaths and 120,000 more hospitalizations owing to poverty-related diseases.

The negative effects of chronic degenerative diseases also deserve consideration. After all, the study "Disease Burden in Brazil" indicated a high burden of mental disorders, with depression being of a particularly larger magnitude within this 
group $^{43}$. It is important to consider the repercussions of limited access to health services against the backdrop of an aging population with a high prevalence of chronic diseases - almost $77 \%$ of the country's total disease burden ${ }^{43}$ - and, consequently, an increase in comorbid populations. Such repercussions could be particularly grave given the limitations imposed upon the SUS with respect to limited access to medium and highly complex care, which are essential to treat patients with chronic diseases. In such circumstances, increases can be expected in morbidity, complications and secondary effects. Reduced detection rates - a possible result of lacking access - would impact on a number of diseases. For example, in cases of cancer such a scenario can entail late diagnosis and, in several cases, the impossibility of providing effective therapy. This could reduce survival rates in Brazil, which are already considered inferior to those of developed countries, even more.

Mckee et al..$^{44}$ point out that, in several European countries, the adoption of measures aimed at reducing public expenditure had different impacts depending on the strength of their health systems and the socio-economic conditions of their populations. In countries with weaker health systems and a higher proportion of populations in situations of vulnerability, such strategies had disastrous effects and nearly collapsed the health system, such as the case of Spain. Already under-financed systems become very compromised by austerity measures, as Labonté \& Stuckler ${ }^{17}$ have pointed out in the case of Europe. When health systems are fragmented, greater imbalance is observed in forming a corps of health professionals in regard to both the structure of specialty services and regional allocations $s^{45}$.

The singularities of Latin America and the relevance of the impacts observed in developed countries behooves Brazil's scientific community to take the responsibility of incorporating this topic into its research agenda. Changes in health sector investments have taken place with little or no participation from academy, users and even sub-national governments. Considering the evidence observed from developed countries, it appears vital to us that evidence also be produced in developing countries. Additionally, alternative options should be created to mitigate the effects of the economic crisis taking into consideration not only the sustainability of public finance but also public well-being and potential risks of a regressive health trend in several countries.

\section{Collaborations}

R Paes-Sousa had contributed to the article design and to the methodological approach. $\mathrm{He}$ had consolidated the overall contributions and the final writing. JMA Schramm had contributed to the literature review, writing and editing. LPM Villarinho had contributed to the literature review, writing and editing. 


\section{References}

1. Martorano B. Taxation and Inequality in Developing Countries: Lessons from the Recent Experience of Latin America. J Int Dev 2018; 30(2):256-273.

2. Stuckler D, Basu S. The Body Economic: Why Austerity Kills. New York: Basic Books; 2013.

3. Paim JS. Sistema Único de Saúde (SUS) aos 30 anos. Ciên Saude Colet 2018; 23(6):1723-1728.

4. Bahia L, Scheffer M. Planos e seguros privados de saúde. In: Giovanella L, Escorel S, Lobato LVC, Noronha JC, Carvalho AI, organizadores. Políticas e sistema de saúde no Brasil [livro na Internet]. Rio de Janeiro: Fiocruz; 2012. [acessado 19 Fev 2018]. p. 427-456. Disponível em: http://pesquisa.bvs.br/brasil/ resource/pt/lil-670008

5. Gragnolati M, Lindelow M, Couttolenc B. Twenty Years of Health System Reform in Brazil: An Assessment of the Sistema Único de Saúde [Internet]. Washington, DC: World Bank; 2013. [acessado 29 Jan 2018]. Disponível em: http://elibrary.worldbank.org/doi/ book/10.1596/978-0-8213-9843-2

6. Massuda A, Hone T, Leles FAG, Castro MC, Atun R. The Brazilian health system at crossroads: progress, crisis and resilience. BMJ Glob Health 2018; 3(4):e000829.

7. Schramm JMA, Paes-Sousa R, Mendes LVP. Políticas de austeridade e seus Impactos na Saúde [Internet]. Rio de Janeiro: Centro de Estudos Estratégicos/Fiocruz; 2018 (Textos para Debate). [acessado 19 Fev 2018]. Disponível em: http://www.cee.fiocruz.br/sites/default/files/Artigo_Joyce_SEM_APRESENTACAO_0. pdf

8. Abad LA, Lindert PH. Fiscal Redistribution in Latin America Since the Nineteenth Century. In: Bértola L, Williamson J, organizadores. Has Latin American Inequality Changed Direction? Looking Over the Long Run [livro na Internet]. Cham: Springer International Publishing; 2017. [acessado 27 Abr 2019]. p. 243-282. Disponível em: https://doi.org/10.1007/978-3-31944621-9_11

9. Karanikolos M, Mladovsky P, Cylus J, Thomson S, Basu S, Stuckler D, Mackenbach JP, McKee M. Financial crisis, austerity, and health in Europe. Lancet 2013; 381(9874):1323-1331.

10. Reeves A, McKee M, Basu S, Stuckler D. The political economy of austerity and healthcare: cross-national analysis of expenditure changes in 27 European nations 1995-2011. Health Policy Amst Neth 2014; 115(1):1-8.

11. Simou E, Koutsogeorgou E. Effects of the economic crisis on health and healthcare in Greece in the literature from 2009 to 2013: a systematic review. Health Policy Amst Neth 2014; 115(2-3):111-119.

12. Grigorakis N, Floros C, Tsangari H, Tsoukatos E. Out of pocket payments and social health insurance for private hospital care: Evidence from Greece. Health Policy Amst Neth 2016; 120(8):948-959.

13. Vieira FS. Qualificação dos serviçes farmacêuticos no Brasil: Aspectos inconclusos da agenda do Sistema Único de Saúde. [Providing quality pharmaceutical services in Brazil: items pending the unified health on the Unified Health System's agenda]. Rev Panam Salud Publica 2008; 24(2):91-100.
14. Vieira FS. Crise econômica, austeridade fiscal e saúde: que lições podem ser aprendidas? [Internet]. Brasília: IPEA; 2016 (Nota Técnica no 26). [acessado $19 \mathrm{Fev}$ 2018]. Disponível em: http://repositorio.ipea.gov.br/ handle/11058/7266

15. Maeda JLK, Henke RM, Marder WD, Karaca Z, Friedman BS, Wong HS. Association between the unemployment rate and inpatient cost per discharge by payer in the United States, 2005-2010. BMC Health Serv Res 2014; 14:378.

16. Kentikelenis A, Karanikolos M, Reeves A, McKee M, Stuckler D. Greece's health crisis: from austerity to denialism. Lancet 2014; 383(9918):748-753.

17. Labonté R, Stuckler D. The rise of neoliberalism: how bad economics imperils health and what to do about it. J Epidemiol Community Health 2016; 70(3):312318.

18. De Vogli R. The financial crisis, health and health inequities in Europe: the need for regulations, redistribution and social protection. Int J Equity Health 2014; 13:58.

19. Gallus S, Ghislandi S, Muttarak R. Effects of the economic crisis on smoking prevalence and number of smokers in the USA. Tob Control 2015; 24(1):82-88.

20. Mulia N, Zemore SE, Murphy R, Liu H, Catalano R. Economic loss and alcohol consumption and problems during the 2008 to 2009 U.S. recession. Alcohol Clin Exp Res 2014; 38(4):1026-1034.

21. Belvis AG, Ferrè F, Specchia ML, Valerio L, Fattore G, Ricciardi W. The financial crisis in Italy: implications for the healthcare sector. Health Policy Amst Neth 2012; 106(1):10-16.

22. Bosque-Prous M, Espelt A, Sordo L, Guitart AM, Brugal MT, Bravo MJ. Job Loss, Unemployment and the Incidence of Hazardous Drinking during the Late 2000s Recession in Europe among Adults Aged 50-64 Years. PloS One 2015; 10(10):e0140017.

23. Regidor E, Vallejo F, Granados JAT, Viciana-Fernández FJ, de la Fuente L, Barrio G. Mortality decrease according to socioeconomic groups during the economic crisis in Spain: a cohort study of 36 million people. Lancet 2016; 388(10060):2642-2652.

24. Karanikolos M, Heino P, McKee M, Stuckler D, Legido-Quigley H. Effects of the Global Financial Crisis on Health in High-Income Oecd Countries: A Narrative Review. Int J Health Serv Plan Adm Eval 2016; 46(2):208-240

25. Phillips JA, Nugent CN. Suicide and the Great Recession of 2007-2009: the role of economic factors in the 50 U.S. states. Soc Sci Med 2014; 116:22-31.

26. Reeves A, McKee M, Gunnell D, Chang S-S, Basu S, Barr B, Stuckler D. Economic shocks, resilience, and male suicides in the Great Recession: cross-national analysis of $20 \mathrm{EU}$ countries. Eur J Public Health 2015 25(3):404-409.

27. Fowler KA, Gladden RM, Vagi KJ, Barnes J, Frazier L. Increase in suicides associated with home eviction and foreclosure during the US housing crisis: findings from 16 National Violent Death Reporting System States, 2005-2010. Am J Public Health 2015; 105(2):311-316 
28. Quaglio G, Karapiperis T, Van Woensel L, Arnold E, McDaid D. Austerity and health in Europe. Health Policy Amst Neth 2013; 113(1-2):13-19.

29. Goldman-Mellor SJ, Saxton KB, Catalano RC. Economic Contraction and Mental Health: A Review of the Evidence, 1990-2009. Int J Ment Health 2010; 39(2):6-31.

30. Martin-Carrasco M, Evans-Lacko S, Dom G, Christodoulou NG, Samochowiec J, González-Fraile E, Bienkowski P, Gómez-Beneyto M, Dos Santos MJ, Wasserman D. EPA guidance on mental health and economic crises in Europe. Eur Arch Psychiatry Clin Neurosci 2016; 266(2):89-124.

31. Merzagora I, Mugellini G, Amadasi A, Travaini G. Suicide Risk and the Economic Crisis: An Exploratory Analysis of the Case of Milan. PloS One 2016; 11(12):e0166244.

32. Barceló MA, Coll-Negre M, Coll-de-Tuero G, Saez M. Effects of the Financial Crisis on Psychotropic Drug Consumption in a Cohort from a Semi-Urban Region in Catalonia, Spain. PloS One 2016; 11(2):e0148594.

33. Kentikelenis A, Karanikolos M, Williams G, Mladovsky P, King L, Pharris A, Suk JE, Hatzakis A, McKee M, Noori T, Stuckler D. How do economic crises affect migrants' risk of infectious disease? A systematic-narrative review. Eur J Public Health 2015; 25(6):937-944.

34. Suhrcke M, Stuckler D, Suk JE, Desai M, Senek M, McKee M, Tsolova S, Basu S, Abubakar I, Hunter P, Rechel B, Semenza JC. The impact of economic crises on communicable disease transmission and control: a systematic review of the evidence. PloS One 2011; 6(6):e20724.

35. Reeves A, Basu S, McKee M, Sandgren A, Stuckler D, Semenza JC. Tuberculosis control and economic recession: longitudinal study of data from 21 European countries, 1991-2012. Bull World Health Organ 2015; 93(6):369-379.

36. Andrikopoulos G, Tzeis S, Terentes-Printzios D, Varounis C, Vlachopoulos C, Mantas I, Patsilinakos S, Lampropoulos S, Olympios C, Kartalis A, Manolis A, Gotsis A, Triposkiadis F, Tsaknakis T, Goudevenos I, Kaprinis I, Pras A, Vasiliou F, Skoumpourdis E, Sakka G, Draganigos A, Vardas P. Impact of income status on prognosis of acute coronary syndrome patients during Greek financial crisis. Clin Res Cardiol Off $J$ Ger Card Soc 2016; 105(6):518-526.

37. Noelke C, Avendano M. Who suffers during recessions? Economic downturns, job loss, and cardiovascular disease in older Americans. Am J Epidemiol 2015; 182(10):873-882.
38. Loerbroks A, Bosch JA, Douwes J, Angerer P, Li J. Job insecurity is associated with adult asthma in Germany during Europe's recent economic crisis: a prospective cohort study. J Epidemiol Community Health 2014; 68(12):1196-1199.

39. Malta DC, Duncan BB, Barros MBA, Katikireddi SV, Souza FM, Silva AG, Machado DB, Barreto ML. Medidas de austeridade fiscal comprometem metas de controle de doenças não transmissíveis no Brasil. Ciên Saude Colet 2018; 23(10):3115-3122.

40. Economic Commission for Latin America and the Caribbean (ECLAC). Statistical Yearbook for Latin America and the Caribbean 2018 [anuário na Internet]. Santiago: ECLAC; 2019. [acessado 27 Abr 2019]. Disponível em: https://repositorio.cepal.org//handle/11362/44445

41. Economic Commission for Latin America and the Caribbean (ECLAC). Statistical Yearbook for Latin America and the Caribbean 2016 [anuário na Internet]. Santiago: ECLAC; 2017. [acessado 27 Abr 2019] Disponível em: https://repositorio.cepal.org//handle/11362/40972

42. Rasella D, Basu S, Hone T, Paes-Sousa R, Ocké-Reis $\mathrm{CO}$, Millett C. Child morbidity and mortality associated with alternative policy responses to the economic crisis in Brazil: A nationwide microsimulation study. PLOS Med 2018; 15(5):e1002570.

43. Leite IC, Valente JG, Schramm JMA, Daumas RP, Rodrigues RN, Santos MF, Oliveira AF, Silva RS, Campos MR, Mota JC. Carga de doença no Brasil e suas regiões, 2008. Cad Saude Publica 2015; 31(7):15511564.

44. McKee M, Karanikolos M, Belcher P, Stuckler D. Austerity: a failed experiment on the people of Europe. Clin Med Lond Engl 2012; 12(4):346-350.

45. Groenewegen PP, Jurgutis A. A future for primary care for the Greek population. Qual Prim Care 2013; 21(6):369-378.

Artigo apresentado em 30/12/2018

Aprovado em 12/07/2019

Versão final apresentada em 09/08/2019 